\title{
MicroRNA networks direct neuronal development and plasticity
}

\author{
N. F. M. Olde Loohuis • A. Kos • G. J. M. Martens • \\ H. Van Bokhoven $\cdot$ N. Nadif Kasri $\cdot$ A. Aschrafi
}

Received: 29 April 2011/Revised: 24 June 2011 / Accepted: 21 July 2011/Published online: 11 August 2011

(C) The Author(s) 2011. This article is published with open access at Springerlink.com

\begin{abstract}
MicroRNAs (miRNAs) constitute a class of small, non-coding RNAs that act as post-transcriptional regulators of gene expression. In neurons, the functions of individual miRNAs are just beginning to emerge, and recent studies have elucidated roles for neural miRNAs at various stages of neuronal development and maturation, including neurite outgrowth, dendritogenesis, and spine formation. Notably, miRNAs regulate mRNA translation locally in the axosomal and synaptodendritic compartments, and thereby contribute to the dynamic spatial organization of axonal and dendritic structures and their function. Given the critical role for miRNAs in regulating early brain development and in mediating synaptic plasticity later in life, it is tempting to speculate that the pathology of neurological disorders is affected by altered expression or functioning of miRNAs. Here we provide an overview of recently identified mechanisms of neuronal development and plasticity involving miRNAs, and the consequences of miRNA dysregulation.
\end{abstract}

Keywords MicroRNA - Neuronal development . Synapse $\cdot$ Learning and memory $\cdot$ Neurological diseases

N. F. M. Olde Loohuis - A. Kos · H. Van Bokhoven •

N. Nadif Kasri · A. Aschrafi $(\bowtie)$

Department of Cognitive Neuroscience, Radboud University

Nijmegen, 6500 HB Nijmegen, The Netherlands

e-mail: a.aschrafi@cns.umcn.nl

H. Van Bokhoven

Department of Human Genetics, Radboud University Nijmegen, 6500 HB Nijmegen, The Netherlands

G. J. M. Martens

Department of Molecular Animal Physiology, Radboud University Nijmegen, 6500 HB Nijmegen, The Netherlands

\section{Introduction}

Synaptic development and plasticity are essential processes for fine-tuning brain circuitry during development, and for learning, memory, and cognition. A number of developmental and adult brain disorders are associated with abnormal changes in synaptic connectivity and plasticity, including fragile X syndrome (FXS) and autism [1]. Previous studies have indicated that synaptic plasticity is under tight control via a number of different post-transcriptional mechanisms, such as the ubiquitin-proteasome system [2], translation initiation and elongation [3], and miRNAs [4]. miRNAs have emerged as an important class of small non-coding RNAs, which are highly conserved and involved in a subset of biological processes such as developmental timing, cell proliferation, apoptosis, metabolism, cell differentiation, and morphogenesis [5]. They act to control the expression of sets of genes and entire pathways, and are thus thought of as master regulators of gene expression [6]. A few miRNAs are expressed in mammalian brains specifically, suggesting unique regulatory roles in neuronal development and higher brain function [7]. Recent estimates put the number of human miRNAs at 1100 or more, composing complex regulatory networks that influence the expression of as many as twothirds of all genes [8]. Such a large family of genes could explain some of the difficulties that neurobiologists generally have encountered in their efforts to link individual miRNA genes to mental disorders. Because they are single molecular entities that dictate the expression of fundamental regulatory pathways, miRNAs represent potential drug targets of unprecedented power. Here, we review recent progress in our understanding of the post-transcriptional mechanisms of miRNAs during neuronal development and plasticity. We will emphasize the role of 
miRNAs in regulating pre- and post-synaptic protein synthesis systems essential for long-lasting memory formation in the brain.

\section{miRNA biogenesis and function}

Although most miRNAs are encoded in intergenic regions, miRNA genes are also found in introns or exons of noncoding RNA genes, or within introns of protein-coding genes [9]. The miRNA pathway starts in the nucleus with the RNA polymerase II-mediated transcription of primary (pri-) miRNAs which can be several kilobases $(\mathrm{kb})$ in size (Fig. 1). The stem-loop conformation of pri-miRNAs is recognized by the nuclear protein Drosha. With its RNase III activity, it cleaves the pri-miRNA into a precursor (pre-) miRNA of around 70-80 nucleotides (nts). The specific processing by Drosha is directed by DiGeorge syndrome critical region 8 (DGCR8) protein [10, 11]. DGCR8 increases the activity of Drosha eight fold [11]. Similar to Drosha knockdown (KD), the KD of DGCR8 leads to the accumulation of pri-miRNAs and a decrease in the amount of pre-miRNAs [10, 11]. The Drosha/DGCR8 complex generates a pre-miRNA with a 2 nt $3^{\prime}$ overhang [12, 13] and a stem-loop conformation ideally consisting of $\sim 22$ nts, which will become the mature miRNA later on in the maturation pathway [13]. The characteristic $3^{\prime}$ overhang and stem-loop conformation are essential for miRNA recognition by exportin-5, which transports the pre-miRNA from the nucleus to the cytoplasm with high efficiency in a Ran/GTP-dependent manner [12]. Although the majority of miRNAs are processed by Drosha, there is also miRNA population that bypasses the Drosha/DGCR8 enzyme complex. One of the miRNA subclasses, known as "miRtrons", is encoded in the introns of protein-coding genes, and mimics the structural features of pre-miRNAs. miRtrons are spliced out to form pre-miRNAs that can be further processed through the common miRNA processing cascade [14-17]. Also, shRNA-derived miRNAs and endogenous hairpin-derived siRNAs are processed in a Drosha-independent manner. The expression patterns as well as the functions of these subclasses of miRNAs and

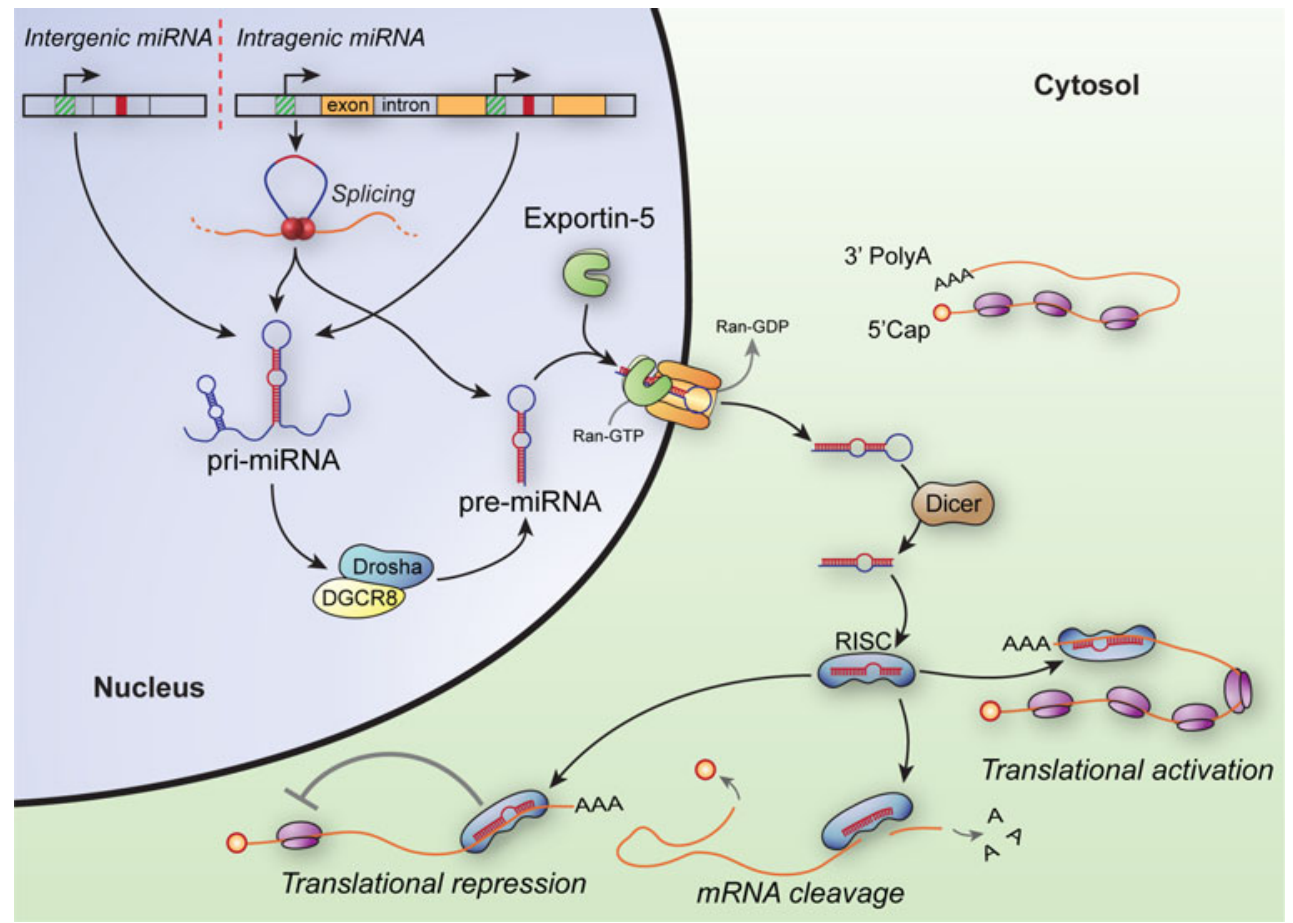

Fig. 1 The biogenesis of miRNAs. Pri-miRNAs are transcribed from intergenic genes and later capped and polyadenylated. Alternatively, miRNAs transcription can occur from genes coded within introns of coding or non-coding genes. Pri-miRNA transcripts are processed into a pre-miRNA by the Drosha/DGCR8 complex, creating a $\sim 70-80$ nts, hairpin-looped molecule, which is then shuttled out of the nucleus via the exportin-5 mediated transport. Some intronicencoded miRNAs evade nuclear processing prior to nuclear export. Cytoplasmatic digestion of the pre-miRNA is facilitated by Dicer, resulting in double-stranded mature miRNAs. Mature miRNAs modulate gene expression by associating with Argonaute-containing complexes to form the RNA induced silencing complex (RISC). By imperfectly or near-perfectly base pairing with sequences in the $3^{\prime}$ UTRs of target mRNAs, miRNAs modulate gene expression through transcript destabilization and translational attenuation. Alternatively, mRNA deadenylation and decapping precedes mRNA cleavage, a process depending on the degree of base-pairing [126]. Some miRNAs can enhance translation upregulation of target mRNAs on cell cycle arrest, while repressing translation in proliferating cells [127] 
siRNAs in mammalian somatic tissues is a yet unexplored area [14]. Moreover, different subclasses of small nucleolar RNAs (snoRNAs), which fulfill miRNA-related functions outside of the nucleolus, are found to be processed independently of Drosha.

In the cytoplasm, pre-miRNAs are recognized and processed by the RNase III Dicer. Dicer KO in Caenorhabditis elegans [18, 19] and mammalian cell lines [20] resulted in the accumulation of cytoplasmatic pre-miRNA. This was first demonstrated for let-7, a miRNA highly conserved among many species, with an essential role in developmental timing in C. elegans and Drosophila [18-21], and prominently involved in many forms of cancer [21]. Fragile $\mathrm{X}$ mental retardation protein (FMRP) interacts with RNAs of around $80 \mathrm{nts}$ and with Dicer in vivo. The complex immunoprecipitated with anti-FMRP antibodies is able to process the long double-stranded pre-miRNAs into mature miRNAs of around 22 nts [23]. An exception on this Dicerdependent miRNA processing is miR-451, which instead uses AGO2 slicer catalytic activity in order to be processed into a mature miRNA. The use of this alternative processing pathway is accomplished by the structural conformation of miR-451 [25]. Once processed into their mature form, miRNAs enter the miRNA silencing complex (miRISC) to degrade or silence mRNAs. During this process, the miRISC complex is supported by a set of proteins, among which Argonaute (AGO)1, AGO2, Pumilio2 (Pum2), and Moloney leukemia virus (MOV10). Within this miRISC complex, AGO1 directly associates with miRNAs [22], and in addition interacts with FMRP [23]. Similarly, AGO2 interacts with mature miRNAs captured in the miRISC complex, and suppression of AGO2 reduced the ability of cells to silence exogenous reporters [24].

Each miRISC-incorporated mature miRNA can act on the expression levels of many mRNAs and conversely individual mRNAs can be targeted by a number of miRNAs. This allows for vast combinatorial complexity that could partly account for the genetic complexity associated with a multitude of essential biological processes. While mRNA targeting and regulation in plants requires a nearperfect complementarity between mature miRNA and the target mRNAs, in animals miRNAs regulate gene expression by imperfect or near-perfect base pairing to mostly the $3^{\prime}$ untranslated region (UTR) of target mRNAs, thereby inhibiting protein synthesis or causing mRNA degradation [26]. miRNA-mediated translational inhibition or mRNA degradation in addition depends on the $5^{\prime}$ cap region of the target mRNAs, since it was shown that miRNAs are able to inhibit the translation of $\mathrm{m} 7 \mathrm{G}$-capped mRNAs but not of mRNAs with an internal ribosome entry site or with a nonfunctional ApppN cap [27, 28]. In eukaryotic cells, mRNAs are circularized by initiation factors, among which eIF4E and poly(A)-binding protein 1 [29]. AGO proteins stimulate miRNA-dependent inhibition of translation by competing with eIF4E for the $5^{\prime}$ cap binding site, thereby preventing circularization of the mRNA and thus lowering the initiation efficiency and at the same time sensitizing the $\operatorname{poly}(\mathrm{A})$ tail for exonuclease [28].

\section{Neuronal localization of miRNAs}

The expression of miRNAs in the brain can be ubiquitous or restricted to a specific brain region, e.g., the hippocampus, cortex, or amygdala [30-32]. This regional specificity in miRNA expression reflects the differences in mRNA composition of cells within various brain tissues and their need for a selection of miRNAs. This notion offers the possibility to establish cell- and tissue-specific miRNA functions by identifying their target mRNAs. Several recent studies have shown subcellular localization of miRNAs within neuronal dendrites of the forebrain [33] and the hippocampus [34]. In synaptoneurosomes, representing the dendritic spines of the neuronal cells, premiRNA levels are high in comparison to the levels of mature miRNAs. In synaptosomes consisting mainly of axon terminals and the adherent post-synaptic densities, pre-miRNAs are enriched as well. miRNAs are thus delivered at the synapse predominantly in their premature forms, destined to be processed locally in correspondence with neuronal conditions [33]. miR-26a was found to be one of the miRNAs most enriched in the dendrites. Sequence-specific miRNA KD identified microtubuleassociated protein 2(MAP2) mRNA as a target for miR-26a. This miRNA reduces microtubule assembly during synaptic plasticity through inhibition of MAP2 mRNA translation [34].

miRNAs have been shown to be present in the axonal compartments where they can actively regulate local mRNA translation. Key proteins involved in the RNAi/ miRNA pathway, i.e., miRISC complexes, can assemble and function in developing axons [35]. Recently, NateraNaranjo [36] and colleagues employed compartmentalized Campenot cell culture chambers to obtain a pure axonal RNA fraction of superior cervical ganglia (SCG) neurons, and determined the miRNA expression levels in these subcellular structural domains. Their data revealed stable expression of a number of mature miRNAs that were enriched in the axons and at presynaptic nerve terminals. Among the 130 miRNAs identified in the axon, miR-15b, miR-16, miR-204, and miR-221 were found to be highly abundant in distal axons as compared to the cell bodies. Interestingly, a number of miRNAs encoded by a common pri-miRNA transcript were differentially expressed in the distal axons, suggesting that there is a differential subcellular transport of miRNAs derived from the same coding 
region of the genome. In addition, Aschrafi et al. [37] used the same compartmentalized cell culture setting and identified miR-338 as a novel modulator of the intra-axonal translation of cytochrome $\mathrm{c}$ oxidase IV (COXIV) mRNA, a nuclear-encoded mitochondrial protein that plays a ratelimiting role in the assembly of the mitochondrial enzyme complex IV and in oxidative phosphorylation. Regulation of axonally localized COXIV mRNA by miR-338 resulted in a decrease in mitochondrial activity, as measured by the reduction of cellular oxygen consumption and ATP levels. Despite increasing evidence for the existence of miRNAs in axons obtained from cell culture experiments, the in vivo relevance of axonal miRNAs in local translation is still unknown. Moreover, little is known about the mechanism of selective miRNA transport into neuronal endings [38].

\section{Molecular basis of local synaptic translation}

While the majority of neuronal mRNAs are translated in the neuronal soma, increasing evidence from more than three decades of neurobiological research suggests that a fraction of the neuronal transcriptome is selectively transported to distal domains of the neuron. The local translation of these mRNAs has a key role in neuronal development, including neuronal survival [39], navigation of the axon [40-45], axonal regeneration [46, 47], synapse formation [48], and activity-dependent synaptic plasticity [49-52]. Notably, a fundamental observation in the field of learning and memory is that new proteins must be synthesized locally at the synapse in order to consolidate newly formed memories [53]. In addition, several Mendelian forms of intellectual disability, such as FXS are caused by changes in synaptic plasticity as a major cellular correlate of their neuropathological phenotypes [54]. As with memory, the stabilization of several distinct forms of activity-dependent synaptic plasticity requires a wave of post-synaptic protein synthesis in the dendrites of neurons. Each form of synaptic plasticity has very distinct characteristics, such as the activation of specific signaling cascades and receptor internalization or surface expression, suggesting that different sets of proteins are required to consolidate the different forms of plasticity [55]. mRNA transport and subsequent protein synthesis at specific synaptic sites allow regulation at the level of individual synapses, a process required for proper neuronal and behavioral plasticity [56-61]. The local distinction between synapses that undergo long-term potentiation (LTP) and synapses that do not, lies within the ability of a synapse to use the proteins made upon neuronal stimulation: only synapses that receive neuronal stimuli will be able to use the proteins made by the activity-induced transcription [59, 62]. The advantage of site-specific translation is that only a few mRNA copies have to be transported to the synapses which in turn can be translated multiple times, whereas multiple proteins produced in the soma from the same mRNA would have to be transported to the synapses [63]. Regulation of local mRNA translation alters the synaptic protein content upon neuronal stimulation by changing the amount of proteins, by changing the entire synaptic proteome through alterations in protein abundance relative to each other, or by the expression of protein isoforms [56, 62].

Many studies have identified a number of mRNAs localized in the dendrites of neurons and thus representing candidates being linked to synaptic plasticity [34, 64-66]. These dendritic mRNAs encode proteins involved in multiple cellular processes regulating spine activity, including signal transduction, mRNA translation, protein transport and degradation, cytoskeleton regulation, and RNA binding and silencing. Among the locally synthesized signaling pathway components are the mitogen-activated protein kinase (MAPK), calcium/calmodulin-dependent protein kinase (CaMK) and protein kinase C (PKC) pathways, which are needed for the induction of morphological changes in synaptic connections and for the maintenance of LTP [65]. Importantly, mRNAs encoding proteins that are essential for translation are also dendritically localized, such as mRNAs coding for the eukaryotic initiation factors eIF4 $\gamma 2$, eIF3 and eIF5 [64], and elongation factors EF1 $\alpha$, EF2 [64] and eEF1A [65], suggesting that local translation is tightly regulated at multiple levels. Furthermore, mRNAs encoding proteins that participate in neuronal outgrowth and spine formation were detected at the spines, among which FMRP, Pum2, and activity-regulated cytoskeleton-associated protein (Arc). FMRP is required for activity-dependent translation [60], Pum2 regulates eIF4Edependent mRNA translation, dendritic morphology and neuronal excitability, and Arc is involved in $\alpha$-amino-3hydroxy-5-methyl-4-isoxazolepropionic acid receptor (AMPAR) internalization. For neurite outgrowth, also cytoskeletal remodeling is required, a process regulated by the locally translated MAP2 [65]. Furthermore, CaMKII and post-synaptic density 95 (PSD-95), fulfilling a scaffolding function at post-synaptic spines, were found to be locally expressed [34].

\section{miRNAs are involved in synaptic maturation and plasticity}

Several studies address the importance of miRNAs in neuronal differentiation and synaptic functionality using KO models of Dicer or DGCR8. Dicer ablation in mice causes impaired neuronal differentiation, reduction in neuronal size, loss of branching and disturbed axonal pathfinding [67-69]. DGCR8 KO mice display deficits in 
synaptic connectivity due to a reduction in the number and size of dendritic spines, reduced synaptic complexity and impaired synaptic transmission [70]. However, by knocking out Dicer or DGCR8 the major part of miRNA processing is blocked, giving an indication of the functions of miRNAs in general. In contrast, studies using single miRNA KD provide a more specific way to investigate the role of individual miRNAs throughout neuronal differentiation steps or during synaptic activation.

Recent findings from studies using single RNA KD also indicate that miRNAs may be involved in modulating local translation and consequently long-term synaptic plasticity (Table 1). The miRISC protein MOV10 regulates miRISCassociated synaptic mRNAs like CaMKII, lim-domaincontaining protein kinase 1 (Limk1) and lysophospholipase 1 (Lypla1). Synaptosomal preparation studies have shown that upon N-methyl-D-aspartate receptor (NMDAR) activation, MOV10 is degraded at the synapses, allowing the translation of synaptic mRNAs that are important for synaptic plasticity [71]. Mature and precursor miRNAs are also located in the soluble component of biochemically isolated synaptic fractions [33]. This finding raises the possibility that miRNAs are formed locally via the processing of pre-miRNAs within dendritic spines.

Upon induction of LTP or long-term depression (LTD), several miRNAs are upregulated in the adult mouse hippocampus. Most miRNAs are rapidly upregulated within 15 min after chemical LTP or metabotropic glutamate receptor (mGluR)-dependent LTD induction. While the majority of the miRNAs have been shown to be upregulated by both LTP and LTD, temporal expression patterns seem to differ between these two forms of plasticity [72]. Following high frequency stimulation in the dentate gyrus (DG), miR132 and miR-212 are upregulated [73]. In the adult DG, transcription of pri-miR-132 and pri-miR-212 strongly depends on mGluR, rather than NMDAR activation. Recently, Goodman and associates created a conditional KO mouse lacking miR-132 and/or miR-212, and examined the involvement of these miRNAs in the maturation of dendrites of newborn neurons in the adult hippocampus. Simultaneous deletion of the miR-132/212 genes caused a dramatic decrease in dendritic length, arborization, and spine density. Out of the miRNAs generated from this locus, miR-132 is proposed to be the miRNA responsible for normal dendrite maturation in newborn hippocampal neurons. Also, ablation of miR-132/212 has similar effects on dendritic development as the loss of cAMP response element-binding (CREB), and miR-132 inhibitors can block the effects of CREB on dendritic maturation, suggesting that miR-132 is involved in CREB signaling [74].

KO studies targeting miR-124 [75], miR-125b [76], miR-132 [77], miR-134 [78, 79], miR-137 [80], and miR138 [81], convincingly revealed the roles of these miRNAs in synaptic development and dendritic arborization. miR124 is the most abundant miRNA in the mouse brain as it accounts for $25-48 \%$ of all brain-expressed miRNAs [82]. Transfection of mouse neuronal stem cells with miR-124 stimulates neuron-like differentiation by promoting neuron-specific neuron-specific class III beta-tublin 1 (Tuj1) and MAP2 expression, and causing G0/G1 cell cycle arrest [83]. In differentiating mouse P19 cells as well as in primary cortical neurons, miR-124 targets the Rho GTPase family. By targeting cell division cycle 42 (Cdc42) and deactivating ras-related $\mathrm{C} 3$ botulinum toxin substrate 1 (Rac1) of the Rho GTPase family, miR-124 diminishes F-actin density and stimulates tubulin acetylation and possibly regulates cytoskeletal reorganization, resulting in the stimulations of neuronal outgrowth (Fig. 2) [84]. In vivo experiments in the mouse subventricular zone (SVZ) have demonstrated that miR-124 downregulates SRY-box containing gene 9 (Sox9) and thereby inhibits precursor division and stimulates differentiation [75]. Overall, miR-124 appears to play a major role in neuronal differentiation by downregulating genes essential for precursor proliferation, while stimulating neuron-specific genes and cytoskeletal rearrangements.

Recently, miR-132 was shown to repress translation of p250GAP, an NMDAR receptor-associated Rho GTPaseactivating protein (GAP), which regulates spine morphogenesis by modulating Rac1 and/or RhoA (Fig. 2). miR-132 expression in rat hippocampus is low during the first postnatal week but accelerates between day 7 and 21, correlating with a period of active synaptogenesis. Conversely, p250GAP expression is high early in development and decreases during maturation. In organotypical hippocampal neurons, inhibition of miR-132 attenuates activityinduced spine formation and decreases spine head size, whereas introduction of miR-132 was sufficient to increase spine formation. Likewise, KD of p250GAP increases spine density and spine size, and furthermore increased both mEPSC frequency and the number of GluR1-positive spines. Additionally, miR-132/p250GAP signaling regulates Rac1 activity and spine formation by modulating synapse-specific kalirin7/Rac1/Pak signaling [85]. Notably, miR-132 together with miR-125b were recently shown to form a functional interaction with FMRP [76] (see below). Overexpression of miR-132 led to an increase in mean mEPSC amplitude and frequency, a phenotype that was prevented by the KD of FMRP. These data suggest that, through the regulation of p250GAP and Rac1 signaling, FMRP and miRNA-132 can cooperate to control synaptic structure and function and potentially explain the spine and behavioral phenotype observed in FXS patients. Indeed, a few reports have linked FMRP's effect on spine morphology to the Rac1 GTPase signaling pathway. The mRNA encoding Rac1 was found to be present in 
Table 1 An overview of selected miRNAs involved in neuronal growth and plasticity

\begin{tabular}{|c|c|c|c|}
\hline miRNA & Neuronal function & mRNA target & Reference \\
\hline miR-9 & Directs ES cells towards a neuronal state & Phospho-STAT3 ${ }^{\mathrm{a}}$ & [91] \\
\hline miR-9 & $\begin{array}{l}\text { Enhances differentiation of neuronal stem cells } \\
\text { Attenuates neural proliferation } \\
\text { Promotes neuronal migration in the developing cortex }\end{array}$ & TLX & [92] \\
\hline miR-9 & $\begin{array}{l}\text { Promotes Cajal-Retzius cell differentiation } \\
\text { Regulates neurogenesis } \\
\text { miR-9 KO mice show impaired brain development }\end{array}$ & $\begin{array}{l}\text { Foxg1 } \\
\text { Gsh2 }\end{array}$ & {$[93,94]$} \\
\hline $\operatorname{miR}-124$ & $\begin{array}{l}\text { Negative constraint on serotonin-induced long-term facilitation } \\
\text { Converts short-term to long-term synaptic facilitation }\end{array}$ & CREB1 & {$[115]$} \\
\hline $\operatorname{miR}-124$ & Increases the number of primary neurites in cortical neurons & $\begin{array}{l}\operatorname{Cdc} 42^{\mathrm{a}} \\
\operatorname{Rac} 1^{\mathrm{a}}\end{array}$ & [84] \\
\hline $\operatorname{miR}-124$ & $\begin{array}{l}\text { Promotes neuronal differentiation of neuronal stem cells } \\
\text { Stimulates neurite branching } \\
\text { Increases the level of neuronal marker Tuj1 }\end{array}$ & CDK6 & {$[83]$} \\
\hline $\operatorname{miR}-125 b$ & $\begin{array}{l}\text { FMRP-associated } \\
\text { Stimulates dendritic branching } \\
\text { Reduces spine width } \\
\text { Weakens synaptic transmission }\end{array}$ & $\begin{array}{l}\text { NR2A } \\
\text { EphA4 }\end{array}$ & [76] \\
\hline $\operatorname{miR}-128$ & $\begin{array}{l}\text { Promotes neuronal differentiation } \\
\text { Enhances dendrite outgrowth }\end{array}$ & $\begin{array}{l}\text { UPF1 } \\
\text { MLN51 }\end{array}$ & [95] \\
\hline $\operatorname{miR}-132$ & Induces neural outgrowth & & [77] \\
\hline $\operatorname{miR}-132$ & $\begin{array}{l}\text { Expression is regulated by CREB } \\
\text { Increases dendritic length, branching, and spine density } \\
\text { Neuronal development and maturation in vivo }\end{array}$ & & [74] \\
\hline $\operatorname{miR}-132$ & $\begin{array}{l}\text { FMRP-associated } \\
\text { Stimulates dendritic complexity } \\
\text { Increases spine width } \\
\text { Strengthens synaptic transmission }\end{array}$ & & [76] \\
\hline $\operatorname{miR}-132$ & $\begin{array}{l}\text { Induces activity-dependent dendritic growth } \\
\text { Triggers de novo spine formation } \\
\text { Stimulates synaptic transmission }\end{array}$ & $\begin{array}{l}\text { p250GAP } \\
\text { Rac1 }^{\text {a }} \\
\text { Kalirin- }^{\text {a }}\end{array}$ & [85] \\
\hline $\operatorname{miR}-132$ & Expression is upregulated by BDNF & $\begin{array}{l}\text { Upregulation of glutamate receptors } \\
\text { NR2 } 2 A^{\mathrm{a}}, N R 2 \mathrm{~B}^{\mathrm{a}} \text {, and GluR } 1^{\mathrm{a}}\end{array}$ & [116] \\
\hline $\operatorname{miR}-134$ & $\begin{array}{l}\text { Modulates cortical development in } \\
\text { a stage-specific manner }\end{array}$ & $\begin{array}{l}\text { Chrdl-1 } \\
\text { Dcx }\end{array}$ & [117] \\
\hline $\operatorname{miR}-134$ & Decreases spine size & LIMK1 & {$[78]$} \\
\hline miR-134 & $\begin{array}{l}\text { Expression is modulated by SIRT1 } \\
\text { Impairs synaptic plasticity/LTP }\end{array}$ & Inhibits translation of CREB & [79] \\
\hline $\operatorname{miR}-137$ & Increases the level of neuronal marker Tuj1 & CDK6 & {$[83]$} \\
\hline $\operatorname{miR}-137$ & Inhibits spine development and phenotypic maturation & Mib1 ubiquitin ligase & {$[80]$} \\
\hline $\operatorname{miR}-138$ & $\begin{array}{l}\text { Regulates spine size negatively } \\
\text { Decreases the amplitude of post-synaptic currents } \\
\text { Decreases in AMPAR cluster size }\end{array}$ & APT1 & {$[71,81]$} \\
\hline $\operatorname{miR}-219$ & Expression is downregulated by an NMDAR antagonist & CaMKII & [108] \\
\hline $\operatorname{miR}-375$ & $\begin{array}{l}\text { Represses the density of dendrites } \\
\text { Diminishes the appearance of neurites after BDNF stimulation }\end{array}$ & $\mathrm{HuD}$ & [118] \\
\hline miR-379/410 cluster & $\begin{array}{l}\text { Transcribed by activation of Mef } 2 \\
\text { Inhibits dendritic outgrowth }\end{array}$ & Pumilio2 (by miR-134) & [89] \\
\hline
\end{tabular}

${ }^{a}$ No direct expression regulation via the identified miRNA shown 


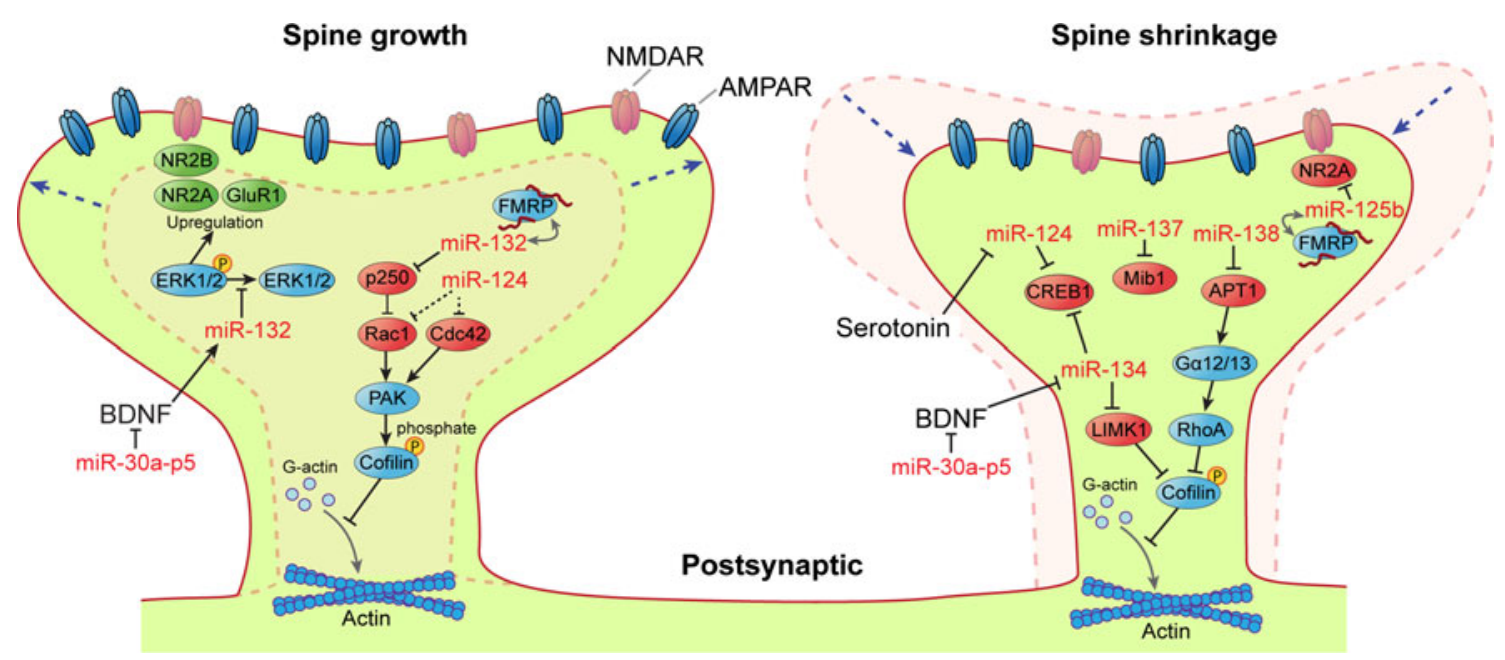

Fig. 2 Overview of miRNAs involved in post-synaptic spine growth or shrinkage with several implicated downstream pathways. The indicated miRNAs can modulate the spine morphologies by targeting components of the actin cytoskeleton, regulate protein expression by targeting transcription factors or (indirectly) targeting components of synaptic ion channels. The molecules involved have been colorcoded, and where red proteins are direct targets of miRNAs, blue proteins depict downstream molecules within the pathways and green proteins are upregulated by miRNAs

proteins, thereby modulating their membrane association. One possible mechanism is that miR-138 activates the Rho signaling pathway by promoting membrane association of $\mathrm{G} \alpha 12 / 13$, one of the targets of APT1 (Fig. 2). Although a direct link between miR-138 and Rho has not been established yet, through membrane association the small $\mathrm{G}$ protein subunit $G \alpha 13$ has been shown to be involved in Rho-dependent signaling [81].

In the rat hippocampus, miR-134 levels increase during development, reaching maximum expression levels at P13, when synaptic maturation occurs. Neurogenic differentiation factor 2 (NeuroD2), disks large homolog 2 (DLG2), and Limk1 contain target sequences for miR-134. Limk1 regulates actin filament dynamics, thereby controlling cytoskeletal reorganizations essential in spine outgrowth. While targeting of Limk1 by miR-134 inhibits spine growth, BDNF increases the synthesis of the Limk1 protein by relieving the miR-134 suppression via the TrkB/mTOR pathway (Fig. 2). KD with a miR-134 antisense oligonucleotide increases spine volume and width in primary rat hippocampal neurons [78]. Thus, an interesting theme is emerging in which miRNAs play an important role in synapse development and plasticity by controlling actin cytoskeleton remodeling through Rho GTPase signaling [89]. Since both miR-132 and miR-134 are regulated by activity at the transcriptional level, these data also indicate that Rho signaling can be fine tuned in an activity-dependent manner. Since only a small number of miRNA targets have been validated and shown to be functionally important in vivo so far [90], it will thus be interesting to assess if more Rho signaling proteins are controlled by miRNAs at the level of (local) translation. 
It was recently demonstrated that NAD-dependent histone deacetylase sirtuin 1 (SIRT1) has the capacity to modulate synaptic plasticity through miRNA-134-dependent regulation of the CREB protein [79]. Previously, SIRT1 was shown to have a number of functions linked to cell metabolism and cellular stress responses. Tsai and associates generated transgenic mice that lack SIRT1 deacetylase activity in the brain. These mice exhibited impaired LTP in CA1 neurons and deficits in memory performance. SIRT1 binds to regulatory DNA sequences upstream of the miR-134 locus and inhibits miR-134 expression upon binding. Furthermore, loss-of-function mutants of SIRT1 inhibited CREB activity in vitro. Addition of miR-134-inhibiting oligonucleotides restored CREB activity, indicating that SIRT1 loss-of-function impairs CREB activity through a miR-134-mediated mechanism. The authors overexpressed miR-134 in CA1 neurons to assess the role of miR-134 in synaptic plasticity. miR-134 overexpression impaired hippocampus-dependent memory formation in wild-type mice and LTP induction in hippocampal slice cultures, suggesting that overexpression of this miRNA in CA1 neurons mimics the effects of SIRT1 loss-of-function. The results of this elegant study indicate that SIRT1 has a key role in synaptic plasticity and memory formation by regulating the protein levels of CREB through miR-134-mediated repression [79].

An example of a miRNA involved in development is miR-9, which was shown to be upregulated during differentiation of mouse embryonic stem (ES) cells towards a neural precursor state, suggesting a role for this miRNA in neuronal differentiation. Overexpression of miR-9 directed ES cells towards a neuronal state versus astroglial cells [91]. Zhao and colleagues provided further evidence for the involvement of miR-9 in differentiation by utilizing in utero electroporation to overexpress miR-9 in the developing brain. miR-9 introduction altered migration and premature differentiation of embryonic neural stem cells lining the ventricular zone. Furthermore, miR-9 was shown to regulate tailless gene (TLX), a gene involved in the division of neural stem cells. Inhibition of TLX by miR-9 attenuated neural stem cell proliferation while enhancing differentiation. Interestingly, TLX was found to inhibit miR-9-1 expression by binding to a $3^{\prime}$ genomic sequence, effectively forming a feedback loop regulation during neuronal differentiation [92]. Besides differentiation of ES cells, miR-9 was found to promote generation of CajalRetzius cells in the medial pallium of the developing telencephalon through negative regulation of the forkhead box protein G1 (foxgl) gene [93]. These findings were later confirmed and extended by the generation of a miR-9 KO mouse model [94]. Together, these findings suggest miR-9 as a central regulator of early developmental processes, during which this miRNA modulates the differentiation and migration of ES cells leading to proper formation of specific brain areas.

Recently, Bruno and associates revealed that overexpression of miR-128 activates the expression of genes relevant for neurogenesis and neuronal differentiation through disruption of the non-sense-mediated RNA decay (NMD) machinery. miR-128 has the capacity to modulate neuronal differentiation through upregulation of a battery of NMD target genes, by specifically diminishing the levels of the NMD proteins RNA helicase Regulator of Non-sense Transcripts 1 (UPF1), and metastatic lymph node 51 (MLN51) [95].

\section{miRNA expression is linked to learning behavior in rodents}

Parsons and colleagues gave a first indication of the involvement of specific miRNAs in learning and memory, exploration, and anxiety behavior [96]. Learning and memory is associated with the expression of a number of miRNAs, such as miR-34c, miR-323, miR-378, and miR451. Exploration behavior is correlated with the expression of the same set of miRNAs, except for involvement of the miR-34a-form instead of the c-form. Anxiety behavior is associated with miR-34c and miR-323 expression. Finally, miR-212 expression correlates with grooming duration in anxiety tasks [96].

In another study, hippocampal miRNA expression changes were assessed in mice subjected to an olfactory learning paradigm. When the levels of individual miRNAs were analyzed following training, expression of $14 \mathrm{miR}$ NAs were elevated. Their mRNA targets were linked to processes that included LTD, transcription, RNA binding, and miRNA biogenesis pathways. Since whole hippocampi were used for miRNA profiling, local synaptic miRNA changes of trained animals could not be discriminated [97]. The studies summarized here indicate that miRNAs expressed by hippocampal neurons are possibly involved in hippocampus-dependent learning. Recent findings suggest that in mice learning and memory is enhanced by the loss of miRNAs in the brain. DCGR8 KO mice showed wildtype behavior in the open field test, but deficits when subjected to a prepulse inhibition test. In cognitive tasks, these KO mice showed normal freezing in the contextual and cued fear-conditioning. However, in the spatial working memory-dependent learning task DGCR8 KO mice performance was impaired, thus indicating the involvement of miRNAs in working memory function [70]. Konopka and associates deactivated the gene for Dicer specifically in forebrain neurons of adult mice. At 12 weeks of age, Dicer KO mice showed improved learning and memory in behavioral tests, and mutant neurons exhibited increased 
numbers of a type of dendritic spine that is associated with learning [98]. In vivo KD studies of miRNAs followed by behavioral experiments would be an additional sophisticated approach to delineate the roles of individual miRNAs during experience-dependent plasticity.

\section{miRNAs in neuronal maturation defects and neurological diseases}

Multiple lines of evidence suggest that altered neuronal plasticity and morphology as seen in neurodevelopmental disorders may result from disruption of a common posttranslational process that is under tight regulation by miRNAs [99]. Several intellectual disability (ID) syndromes, such as FXS, Rett syndrome and Down syndrome have been linked to the miRNA pathway [23, 100, 101]. Increasing evidence suggests that miRNAs which act as regulators of neuronal gene circuitries are associated with complex neuropsychiatric disorders involving abnormalities in synaptic plasticity, as well as neurodegenerative diseases. Kosik and coworkers profiled human miRNAs in autism and control post-mortem brains, and identified 28 miRNAs to be differentially expressed in autistic as compared to healthy individuals [102]. Recently, a valproic acid (VPA) rat model of autism was employed to assess the molecular role of miRNAs in the chemically induced, neuroplastic changes observed in autism spectrum disorders (ASD). Chronic VPA treatment of adult rats induced alterations of hippocampal miRNA levels. Levels of let-7, miR-128a, miR-24a, miR-30c, miR-34a, miR-221 and miR-144 were significantly altered, and the predicted effectors of these miRNAs are involved in neurite outgrowth, neurogenesis, signaling of PTEN, ERK, and Wnt/ beta-catenin pathways [103].

Trinucleotide expansions in the $5^{\prime}$ UTR of the fmrl gene leading to reduced FMRP protein levels are associated with FXS, characterized by intellectual disability and autistic features. FMRP is involved in the miRNA pathway through interaction with miRNA biogenesis components or through association with miRNAs directly [104]. Interestingly, Edbauer et al. showed that miR-125b and miR-132, as well as several other miRNAs, are associated with FMRP in mouse brain. More specifically, miR-125b and miR-132 had largely opposing effects on dendritic spine morphology and synaptic physiology in hippocampal neurons. FMRP $\mathrm{KD}$ ameliorates the effect of miRNA overexpression on spine morphology, and NMDAR subunit NR2A was identified as a target of miR-125b [76]. FMRP controls premiR-124 processing into mature miR-124 [105]. Since miR-124 stimulates neuronal differentiation [75, 83, 84], its link with FMRP may suggest roles for this miRNA in FXS patients.
In schizophrenia patients, miR-16b, 30b [106] and 181b are significantly upregulated in the prefrontal cortex [107]. miR-181b downregulates protein levels of the AMPA glutamate receptor subunit GluR2 and of the RNA binding protein visinin-like 1 (VSNL1). GluR2 stimulates excitatory neurotransmission and has direct effects on synaptic plasticity by increasing growth and density of dendritic spines. VSNL1 is stimulated by glutamate and targets the mBDNF receptor TrkB thereby promoting neuronal maturation. Upregulation of miR-181b in schizophrenia patients thus causes a decrease in neuronal outgrowth by targeting GluR2 and VSNL1 [107]. Recent research has identified miR-219 as a key molecule in the behavioral manifestations associated with NMDAR hypofunction, which has been implicated in the pathophysiology of schizophrenia [108], since acute treatment of mice with the NMDAR antagonist dizocilpine resulted in downregulation of miR-219 in mouse prefrontal cortex. Moreover, treatment of mice with the antipsychotic drugs haloperidol or clozapine attenuated the hyperactivity and prevented the reduction in miR-219 in the prefrontal cortex. Notably, infusion of mouse brain with the antisense oligonucleotides (so-called antagomiRs [109]) against miR-219 both attenuated the locomotor and stereotypic behaviors caused by dizocilpine and increased the expression of miR-219 target CaMKII in the prefrontal cortex. This study suggests that altered miR-219 levels could be a significant factor in the dysregulation of cortical gene expression in schizophrenia.

Extensively studied neurodegenerative diseases such as Alzheimer's disease (AD) and Parkinson's disease (PD) also display altered miRNA expression profiles. The expression of the $\beta$-site of APP cleaving enzyme (BACE1) protein stimulates the formation of amyloid- $\beta$-peptide plaques in the brains of AD patients. BACE1 was shown to be targeted by miR-485-5p. A natural antisense transcript, BACE-antisense, however, blocks the binding site for miR-458-5p thereby preventing BACE1-downregulation. BACE-antisense and miR-458-5p compete for the binding to BACE1-mRNA. In AD patients, BACE-antisense appeared to be upregulated while miR-485-5p was downregulated in the entorhinal cortex and the hippocampus, thus increasing the amount of BACE1 protein and thereby amyloid- $\beta$ formation in these brain regions [110]. Additional miRNAs that are dysregulated in $\mathrm{AD}$ are miR-9, miR-138 and miR-125b, the levels of which are increased in the CA1 region of the hippocampus [111].

The maturation of dopaminergic neurons is under the control of miRNAs as well. In mice, induced deletion of Dicer specifically in post-mitotic dopamine neurons yields a phenotype comparable to that of PD patients, namely loss of dopaminergic neurons and reduced locomotion. A specific miRNA involved in dopaminergic maturation is miR$133 \mathrm{~b}$ and its level is increased in PD [112]. miR133b 
Table 2 An overview of selected miRNAs associated with neurological disorders

\begin{tabular}{|c|c|c|c|c|c|}
\hline miRNA & Disease & Dysregulation & Target & Consequence of miRNA dysregulation & Reference \\
\hline \multirow[t]{2}{*}{$\operatorname{miR}-9 / 9 *$} & \multirow[t]{2}{*}{$\begin{array}{l}\text { Huntington } \\
\text { disease }\end{array}$} & \multirow[t]{2}{*}{ Downregulated } & REST (miR-9) & $\begin{array}{l}\text { Excessive amount of REST and } \\
\text { CoREST in the nucleus }\end{array}$ & \multirow[t]{2}{*}{ [119] } \\
\hline & & & CoREST (miR-9*) & Inactivation of neuron-specific genes & \\
\hline $\operatorname{miR}-29 a$ & $\mathrm{AD}$ & Downregulated & NAV3 & $\begin{array}{l}\text { NAV3 coexpressed tau neurofibrillary } \\
\text { tangles in pyramidal neurons }\end{array}$ & {$[120]$} \\
\hline $\operatorname{miR}-29 a,-29 b-1$ & Sporadic AD & Downregulated & BACE1 & Increase of amyloid- $\beta$ & {$[121]$} \\
\hline miR-106b & $\mathrm{AD}$ & Downregulated & APP & Increase of amyloid- $\beta$ & {$[111]$} \\
\hline $\operatorname{miR}-107$ & $\mathrm{AD}$ & Downregulated & BACE1 & Increase of amyloid- $\beta$ & {$[122]$} \\
\hline $\operatorname{miR}-124$ & FXS & Downregulated & & Decreased neuronal maturation & {$[105]$} \\
\hline $\operatorname{miR}-133 b$ & PD & Upregulated & Pitx3 & Repression of neuronal maturation & {$[112]$} \\
\hline $\mathrm{miR}-146 \mathrm{a} / \mathrm{b}$ & Rett syndrome & Downregulated & Irak1 & $\begin{array}{l}\text { An increase in the amount of Irak } 1 \text { puts } \\
\text { the brain into an inflammatory state }\end{array}$ & {$[123]$} \\
\hline $\operatorname{miR}-181 b$ & Schizophrenia & $\begin{array}{l}\text { Upregulated in } \\
\text { prefrontal cortex }\end{array}$ & $\begin{array}{l}\text { GRIA2 } \\
\text { VSNL1 }\end{array}$ & Decrease in neuronal outgrowth & [107] \\
\hline miR-298 and -328 & $\mathrm{AD}$ & Unknown & BACE1 & Increase of amyloid- $\beta$ & {$[124]$} \\
\hline $\operatorname{miR}-342-3 p$ & Prion disease & Upregulated & & & {$[125]$} \\
\hline $\operatorname{miR}-485-5 p$ & $\mathrm{AD}$ & $\begin{array}{l}\text { Downregulated in entorhinal } \\
\text { cortex and hippocampus }\end{array}$ & BACE1 & Increase of amyloid- $\beta$ & {$[110]$} \\
\hline
\end{tabular}

targets the transcription factor pituitary homeobox 3 (Pitx3), which is normally induced during neuronal development. Pitx3 in addition upregulates miR-133b expression, thus generating a feedback circuit. Overall, upregulation of miR-133b expression in PD represses neuronal maturation through the inhibition of Pitx 3 .

From these studies on neurological diseases, it thus appears that miRNAs are essential in neuronal differentiation, dendritic outgrowth, and spine formation. The dysregulation of miRNAs could ultimately underlie some of the clinical features observed in these diseases through their effects on synaptic plasticity. An overview of miRNAs implicated in neurological disorders is provided in Table 2.

Mutations in miRNA genes or gene copy number changes due to genomic deletions and duplications are likely to be involved in neurological disorders. So far, there are no published examples to substantiate this notion, but mutations in miR-96 have been linked to deafness in mice [113]. Moreover, heterozygous mutations in the human SLITRK1 gene have been associated with a variety of neuropsychiatric features including Tourette syndrome, ADHD, and compulsive hair pulling. In Tourette syndrome a single mutation in the $3^{\prime}$ UTR of SLITRK1 disrupts the recognition site of miR-189 [114]. The same mutation was also found in other families with Tourette syndrome and obsessive compulsive disorder, but the mutation was not fully segregated with the disorder, suggesting additional genetic and/or environmental contributions to the disease. Nonetheless, since mutation analysis in human disorders have so far been largely restricted to coding sequences it is to be expected that the rapidly emerging whole-genome sequencing projects will reveal mutations in miRNA genes or their target sequences in human neurodevelopmental disorders.

\section{Future directions}

The unique feature of miRNAs is to modulate complex physiological or disease phenotypes by regulating entire genetic circuitries. The findings reviewed here support the hypothesis that miRNAs are ideally positioned to play a central role in regulating complex gene networks involved in synaptic development and plasticity. This characteristic makes miRNAs attractive and novel therapeutic and diagnostic targets for the treatment and detection of complex intellectual disorders. Ultimately, further identification of individual miRNAs in synaptic function and maintenance will generate original insights into the molecular basis of synaptic plasticity. In the long term, the outcome from these investigations will provide a novel avenue for the identification and development of miRNAs as "molecular tools", with the potential to identify novel molecular pathways involved in synaptic maintenance and generate new molecular-based therapies to treat diseases of the central nervous system.

Acknowledgments The research of the authors is supported by grants from the "Donders Center for Neuroscience fellowship award of the Radboud University Nijmegen Medical Center" [to A.A. and N.N.K.]; the "FP7-Marie Curie International Reintegartion Grant" [to A.A. and N.N.K.]; and GENCODYS, an EU FP7 large-scale integrating project grant [Grant number 241995] [to HvB]. 
Open Access This article is distributed under the terms of the Creative Commons Attribution Noncommercial License which permits any noncommercial use, distribution, and reproduction in any medium, provided the original author(s) and source are credited.

\section{References}

1. Belmonte MK, Allen G, Beckel-Mitchener A, Boulanger LM, Carper RA, Webb SJ (2004) Autism and abnormal development of brain connectivity. J Neurosci 24(42):9228-9231

2. Yashiro K, Riday TT, Condon KH, Roberts AC, Bernardo DR, Prakash R, Weinberg RJ, Ehlers MD, Philpot BD (2009) Ube3a is required for experience-dependent maturation of the neocortex. Nat Neurosci 12(6):777-783

3. Costa-Mattioli M, Sossin WS, Klann E, Sonenberg N (2009) Translational control of long-lasting synaptic plasticity and memory 2. Neuron 61(1):10-26

4. Manakov SA, Grant SG, Enright AJ (2009) Reciprocal regulation of microRNA and mRNA profiles in neuronal development and synapse formation. BMC Genom 10:419

5. Ambros V (2008) The evolution of our thinking about microRNAs. Nat Med 14:1036-1040

6. Martinez NJ, Gregory RI (2010) MicroRNA gene regulatory pathways in the establishment and maintenance of ESC identity. Cell Stem Cell 7(1):31-35

7. Kim J, Krichevsky A, Grad Y, Hayes GD, Kosik KS, Church GM, Ruvkun G (2004) Identification of many microRNAs that copurify with polyribosomes in mammalian neurons. Proc Natl Acad Sci USA 101(1):360-365

8. Krol J, Loedige I, Filipowicz W (2010) The widespread regulation of microRNA biogenesis, function and decay. Nat Rev Genet 11:597-610

9. Kim VN (2005) MicroRNA biogenesis: coordinated cropping and dicing. Nat Rev Mol Cell Biol 6:376

10. Denli AM, Tops BBJ, Plasterk RHA, Ketting RF, Hannon GJ (2004) Processing of primary microRNAs by the microprocessor complex. Nature 432:231-235

11. Gregory RI, Yan KP, Amuthan G, Chendrimada T, Doratotaj B, Cooch N, Shiekhatter R (2003) The microprocessor complex mediates the genesis of microRNAs. Nature 432:235-240

12. Yi R, Qin Y, Macara IG, Cullen BR (2003) Exportin-5 mediates the nuclear export of pre-microRNAs and short hairpin RNAs. Genes Dev 17:3011-3016

13. Gwizdek C, Ossareh-Nazari B, Brownawell AM, Doglio A, Bertrand E, Macara IG, Dargemont C (2002) Exportin-5 mediates nuclear export of minihelix-containing RNAs. J Biol Chem 278(8):5505-5508

14. Babiarz JE, Ruby JG, Wang Y, Bartel DP, Blelloch R (2008) Mouse ES cells express endogenous shRNAs, siRNAs, and other Microprocessor-independent, Dicer-dependent small RNAs. Genes Dev 22(20):2773-2785

15. Berezikov E, Chung WJ, Willis J, Cuppen E, Lai EC (2007) Mammalian mirtron genes. Mol Cell 28(2):328-336

16. Okamura K, Hagen JW, Duan H, Tyler DM, Lai EC (2007) The mirtron pathway generates microRNA-class regulatory RNAs in Drosophila. Cell 130(1):89-100

17. Ruby JG, Jan CH, Bartel DP (2007) Intronic microRNA precursors that bypass Drosha processing. Nature 448(7149):83-86

18. Grishok A, Pasquinelli Ae, Conte D, Li N, Parrish S, Ha I, Baillie DL, Fire A, Ruvkun G, Mello CC (2001) Genes and mechanisms related to RNA interference regulate expression of the small temporal RNAs that control C. elegans developmental timing. Cell 106(1):23-34
19. Ketting RF, Fischer SE, Bernstein E, Sijen T, Hannon GJ, RH Plasterk (2001) Dicer functions in RNA interference and in synthesis of small RNA involved in developmental timing in C. elegans. Genes Dev 15(20):2654-2659

20. Hutvagner G, Mclachlan J, Pasquinelli AE, Balint E, Tuschl T, Zamore PD (2001) A cellular function for the RNA-interference enzyme Dicer in the maturation of the let-7 small temporal RNA. Science 293(5531):834-838

21. Roush S, Slack FJ (2008) The let-7 family of microRNAs. Trends Cell Biol 18(10):505-516

22. Mourelatos Z, Dostie J, Paushkin S (2002) miRNPs: a novel class of ribonucleoproteins containing numerous microRNAs. Genes Dev 16:720-728

23. Jin P, Zarnescu DC, Ceman S, Nakamoto M, Mowrey J, Jongens TA, Nelson DL, Moses K, Warren ST (2004) Biochemical and genetic interaction between the fragile $\mathrm{X}$ mental retardation protein and the microRNA pathway. Nat Neurosci 7(2):113-117

24. Hammond SM, Boettcher S, Caudy AA, Kobayashi R, Hannon GJ (2001) Argonaute2, a link between genetic and biochemical analysis of RNAi. Science 293(5532):1146-1150

25. Cifuentes D, Xue H, Taylor DW, Patnode H, Mishima Y, Cheloufi S, Ma E, Mane S, Hannon GJ, Lawson ND, Wolfe SA, Giraldez AJ (2010) A novel miRNA processing pathway independent of Dicer requires Argonaute 2 catalytic activity. Science 328(5986):1694-1698

26. Huntzinger E, Izaurralde E (2011) Gene silencing by microRNAs: contributions of translational repression and mRNA decay. Nat Rev Genet 12(2):99-110

27. Wakiyama M, Takimoto K, Ohara O, Yokoyama S (2007) Let-7 microRNA-mediated mRNA deadenylation and translational repression in a mammalian cell-free system. Genes Dev 21:1857-1862

28. Mathonnet G, Fabion MR, Svitkin YV, Parsyan A, Huck L, Murata T, Biffo S, Merrich WC, Darzynkiewicz E, Pillai RS, Filipowicz W, Duchaine TF, Sonenberg N (2007) MicroRNA inhibition of translation initiating in vitro by targeting the capbinding complex eIF4F. Science 317:1764-1767

29. Sonenberg N, Dever TE (2003) Eukaryotic translation initiation factors and regulators. Curr Opin Struct Biol 13(1):56-63

30. Bak M, Silahtaroglu A, Meller M (2008) MicroRNA expression in the adult mouse central nervous system. RNA 14:432-444

31. He X, Zhang Q, Liu Y, Pan X (2007) Cloning and identification of novel microRNAs from rat hippocampus. Acta Biochim Biophys Sin 39(9):708-714

32. Olsen L, Klausen M, Helboe L, Nielsen FC, Werge T (2009) MicroRNAs show mutually exclusive expression patterns in the brain of adult male rats. PLoS One 4(10):1-7

33. Lugli G, Torvik VI, Larson J, Smalheiser NR (2008) Expression of microRNAs and their precursors in synaptic fractions of adult mouse forebrain. J Neurochem 106:650-661

34. Kye MJ, Liu T, Levy SF (2007) Somatodendritic microRNAs identified by laser capture and multiplex RT-PCR. RNA 13:1224-1234

35. Hengst U, Cox LJ, Macosko EZ, Jaffrey SR (2006) Functional and selective RNA interference in developing axons and growth cones. J Neurosci 26(21):5727-5732

36. Natera-Naranjo O, Aschrafi A, Gioio AE, Kaplan BB (2010) Identification and quantitative analyses of microRNAs located in the distal axons of sympathetic neurons. RNA 16(8):1516-1529

37. Aschrafi A, Schwechter AD, Mameza MG, Natera-Naranjo O, Gioio AE, Kaplan BB (2008) MicroRNA-338 regulates local cytochrome c oxidase IV mRNA levels and oxidative phosphorylation in the axons of sympathetic neurons. J Neurosci 28(47):12581-12590

38. Kaplan BB, Gioio AE, Hillefors M, Aschrafi A (2009) Axonal protein synthesis and the regulation of local mitochondrial function. Results Probl Cell Differ 48:225-242 
39. Cox LJ, Hengst U, Gurskaya NG, Lukyanov KA, Jaffrey SR (2008) Intra-axonal translation and retrograde trafficking of CREB promotes neuronal survival. Nat Cell Biol 10(2):149-159

40. Campbell DS, Holt CE (2001) Chemotropic responses of retinal growth cones mediated by rapid local protein synthesis and degradation. Neuron 32(6):1013-1026

41. Campbell DS, Regan AG, Lopez JS, Tannahill D, Harris WA, Holt CE (2001) Semaphorin 3A elicits stage-dependent collapse, turning, and branching in Xenopus retinal growth cones. J Neurosci 21(21):8538-8547

42. Leung KM, Horck FP, Lin AC, Allison R, Standart N, Holt CE (2006) Asymmetrical beta-actin mRNA translation in growth cones mediates attractive turning to netrin-1. Nat Neurosci $9(10): 1247-1256$

43. Ming GL, Wong ST, Henley J, Yuan XB, Song HJ, Spitzer NC, Poo MM (2002) Adaptation in the chemotactic guidance of nerve growth cones. Nature 417(6887):411-418

44. Zhang X, Poo MM (2002) Localized synaptic potentiation by BDNF requires local protein synthesis in the developing axon. Neuron 36(4):675-688

45. Aschrafi A, Natera-Naranjo O, Gioio AE, Kaplan BB (2010) Regulation of axonal trafficking of cytochrome c oxidase IV mRNA. Mol Cell Neurosci 43(4):422-430

46. Zhang Y, Tohyama K, Winterbottom JK, Haque NS, Schachner M, Lieberman AR, Anderson PN (2001) Correlation between putative inhibitory molecules at the dorsal root entry zone and failure of dorsal root axonal regeneration. Mol Cell Neurosci 17(3):444-459

47. Hanz S, Perlson E, Willis D, Zheng JQ, Massarwa R, Huerta JJ, Koltzenburg M, Kohler M, Van-Minnen J, Twiss JL, Fainzilber M (2003) Axoplasmic importins enable retrograde injury signaling in lesioned nerve. Neuron 40(6):1095-1104

48. Schacher S, Wu F (2002) Synapse formation in the absence of cell bodies requires protein synthesis. J Neurosci 22(5):1831-1839

49. Beaumont V, Zhong N, Fletcher R, Froemke RC, Zucker RS (2001) Phosphorylation and local presynaptic protein synthesis in calcium- and calcineurin-dependent induction of crayfish long-term facilitation. Neuron 32(3):489-501

50. Martin KC, Casadio A, Zhu H, Yaping E, Rose JC, Chen M, Bailey CH, Kandel ER (1997) Synapse-specific, long-term facilitation of aplysia sensory to motor synapses: a function for local protein synthesis in memory storage. Cell 91(7):927-938

51. Si K, Giustetto M, Etkin A, Hsu R, Janisiewicz AM, Miniaci MC, Kim JH, Zhu H, Kandel ER (2003) A neuronal isoform of CPEB regulates local protein synthesis and stabilizes synapsespecific long-term facilitation in aplysia. Cell 115(7):893-904

52. Wang DO, Kim SM, Zhao Y, Hwang H, Miura SK, Sossin WS, Martin KC (2009) Synapse- and stimulus-specific local translation during long-term neuronal plasticity. Science 324(5934): $1536-1540$

53. Guzowski JF, Lyford GL, Stevenson GD, Houston FP, Mcgaugh JL, Worley PF, Barnes CA (2000) Inhibition of activitydependent arc protein expression in the rat hippocampus impairs the maintenance of long-term potentiation and the consolidation of long-term memory. J Neurosci 20(11):3993-4001

54. Sutton MA, Ito HT, Cressy P, Kempf C, Woo JC, Schuman EM (2006) Miniature neurotransmission stabilizes synaptic function via tonic suppression of local dendritic protein synthesis. Cell 125(4):785-799

55. Vanderklish PW, Edelman GM (2005) Differential translation and fragile X syndrome. Genes Brain Behavior 4(6):360-384

56. Sutton MA, Schuman EM (2006) Dendritic protein synthesis, synaptic plasticity, and memory. Cell 127:49-58

57. Costa-Mattioli M, Sossin WS, Klann E, Sonenberg N (2009) Translational control of long-lasting synaptic plasticity and memory. Neuron 61:10-26
58. Richter JD, Klann E (2009) Making synaptic plasticity and memory last: mechanisms of translational regulation. Genes Dev 23:1-11

59. Bramham CR, Wells DG (2007) Dendritic mRNA: transport, translation and function. Nat Neurosci 8:776-789

60. Aschrafi A, Cunningham BA, Edelman GM, Vanderklish PW (2005) The fragile $X$ mental retardation protein and group I metabotropic glutamate receptors regulate levels of mRNA granules in brain. PNAS 102(6):2180-2185

61. Smart F, Aschrafi A, Atkins A, Owens GC, Pilotte J, Cunningham BA, Vanderklish PW (2007) Two isoforms of the coldinducible mRNA-binding protein RBM3 localize to dendrites and promote translation. J Neurochem 101(5):1367-1379

62. Kandel ER (2001) The molecular biology of memory storage: a dialog between genes and synapses. Biosci Rep 21(5):477-522

63. Wang DO, Martin KC, Zukin RS (2010) Spatially restricting gene expression by local translation at synapses. Trends Neurosci 33(4):173-182

64. Poon MM, Choi SH, Jamieson CAM, Geschwind DH, Martin $\mathrm{KC}$ (2006) Identification of process-localized mRNAs from cultured rodent hippocampal neurons. J Neurosci 26(51): 13390-13399

65. Zhong J, Zhang T, Bloch LM (2006) Dendritic mRNAs encode diversified functionalities in hippocampal pyramidal neurons. BMC Neurosci 7:17

66. Khandjian EW, Huot ME, Tremblay S, Davidovic L, Mazroui R, Bardoni B (2004) Biochemical evidence for the association of fragile X mental retardation protein with brain polyribosomal ribonucleoparticles. Proc Natl Acad Sci 101(36):13357-13362

67. Davis TH, Cuellar TL, Koch SM, Barker AJ, Harfe BD, Mcmanus MT, Ullian EM (2008) Conditional loss of Dicer disrupts cellular and tissue morphogenesis in the cortex and hippocampus. J Neurosci 28(17):4322-4330

68. De Pietri Tonelli D, Pulvers JM, Haffner C, Murchison EP, Hannon GJ, Huttner WB (2008) MiRNAs are essential for survival and differentiation of newborn neurons but not for expansion of neural progenitors during early neurogenesis in the mouse embryonic neocortex. Development 135:3911-3921

69. Schaefer A, O'carroll D, Tan CL, Hillman D, Sugimori M, Llinas R, Greengard P (2007) Cerebellar neurodegeneration in the absence of microRNAs. J Exp Med 204(7):1553-1558

70. Stark KL, Xu B, Bagchi A, Lai WS, Liu H, Hsu R, Wan X, Pavlidis P, Mills AA, Karayiorgou M, Gogos JA (2008) Altered brain microRNA biogenesis contributes to phenotypic deficits in a 22q11-deletion mouse model. Nat Genet 40(6):751-760

71. Banjernee S, Neveu P, Kosik KS (2009) A coordinated local translation control point at the synapse involving relief from silencing and MOV10 degradation. Neuron 64:871-884

72. Park CS, Tang SJ (2009) Regulation of microRNA expression by induction of bidirectional synaptic plasticity. J Neurosci 38:50-56

73. Wibrand K, Panja D, Tiron A, Ofte ML, Skaftnesmo KO, Lee CS, Pena JTG, Tuschl T, Bramham CR (2010) Differential regulation of mature and precursor microRNA expression by NMDA and metabotropic glutamate receptor activation during LTP in the adult dentate gyrus in vivo. Eur $\mathrm{J}$ Neurosci 31:636-645

74. Magill ST, Cambronne XA, Luikart BW, Lioy DT, Leighton BH, Westbrook GL, Mandel G, Goodman RH (2010) microRNA-132 regulates dendritic growth and arborization of newborn neurons in the adult hippocampus. PNAS 107(47):20382-20387

75. Cheng LC, Pastrana E, Tavazoie M, Doetsch F (2009) miR-124 regulates adult neurogenesis in the subventricular zone stem cell niche. Nat Neurosci 12(4):399-408

76. Edbauer D, Neilson JR, Foster KA, Wang CF, Seeburg DP, Batterton MN, Tada T, Dolan BM, Sharp PA, Sheng M (2010) 
Regulation of synaptic structure and function by FMRP-associated microRNAs miR-125b and miR-132. Neuron 65(3):373-384

77. Vo N, Klein ME, Varlamova O, Keller DM, Yamamoto T, Goodman RH, Impey S (2005) A cAMP-response element binding protein-induced microRNA regulates neuronal morphogenesis. PNAS 102(45):16426-16431

78. Schratt GM, Tuebing F, Nigh EA, Kane CG, Sabatini ME, Kiebler M, Greenberg ME (2006) A brain-specific microRNA regulates dendritic spine development. Nature 439(16):283-289

79. Gao J, Wang WY, Mao YW, Graff J, Guan JS, Pan L, Mak G, Kim D, Su SC, Tsai LH (2010) A novel pathway regulates memory and plasticity via SIRT1 and miR-134. Nature 466(7310):1105-1109

80. Smrt RD, Szulwach KE, Pfeiffer RL, Li X, Guo W, Pathania M, Teng ZQ, Luo Y, Bordey A, Peng J, Zhao X (2010) MicroRNA miR-137 regulates neuronal maturation by targeting ubiquitin ligase Mind Bomb-1. Stem cells 28(6):1060-1070

81. Siegel G, Obernosterer G, Fiore R, Oehman M, Bicker S, Christensen M, Khydayberdiev S, Leuschner PF, Busch CJL, Kane C, Hubel K, Dekker F, Hedberg C, Rengarajan B, Drepper C, Waldmann H, Kauppinen S, Greenberg ME, Draguhn A, Rehmsmeier M, Martinez J, Schratt G (2009) A functional screen implicates microRNA-138-dependent regulation of the depalmitoylation enzyme APT1 in dendritic spine morphogenesis. Nat Cell Biol 11:705-716

82. Lagos-Quintana M, Rauhut R, Yalcin A, Meyer J, Lendeckel W, Tuschl T (2002) Identification of tissue-specific microRNAs from mouse. Curr Biol 12(9):735-739

83. Silber J, Lim AD, Petritsch C, Persson AI, Maunakea AK, Yu M, Vanderberg SR, Ginzinger DG, James CD, Costello JF, Bergers G, Weiss WA, Alvarez-Buylla A, Hodgson JG (2008) miR-124 and miR-137 inhibit proliferation of glioblastoma multiforme cells and induce differentiation of brain tumor stem cells. BMC Med 6:14

84. Yu JY, Chung KH, Deo M, Thompson RC, Turner DL (2008) MicroRNA miR-124 regulates neurite outgrowth during neuronal differentiation. Exp Cell Res 314:2618-2633

85. Impey S, Davare M, Lasiek A, Fortin D, Ando H, Varlamova O, Obrietan K, Soderling TR, Goodman RH, Wayman GA (2010) An activity-induced microRNA controls dendritic spine formation by regulating Rac1-PAK signaling. Mol Cell Neurosci 43:146-156

86. Lee Y, Ahn C, Han J, Choi H, Kim J, Yim J, Lee J, Provost P, Radmark O, Kim S, Kim VN (2003) The nuclear RNase III Drosha initiates microRNA processing. Nature 425:415-419

87. Schenck A, Bardoni B, Langmann C, Harden N, Mandel JL, Giangrande A (2003) CYFIP/Sra-1 controls neuronal connectivity in Drosophila and links the Rac1 GTPase pathway to the fragile X protein. Neuron 38(6):887-898

88. Napoli I, Mercaldo V, Boyl PP, Eleuteri B, Zalfa F, De Rubeis S, Di Marino D, Mohr E, Massimi M, Falconi M, Witke W, Costa-Mattioli M, Sonenberg N, Achsel T, Bagni C (2008) The fragile $\mathrm{X}$ syndrome protein represses activity-dependent translation through CYFIP1, a new 4E-BP. Cell 134(6):1042-1054

89. Fiore R, Khudayberdiev S, Christensen M, Siegel G, Flavell SW, Kim TK, Greenberg ME, Schratt G (2009) Mef2-mediated transcription of the miR379-410 cluster regulates activitydependent dendritogenesis by fine-tuning Pumilio2 protein levels. EMBO J 28(6):697-710

90. Christensen M, Larsen LA, Kauppinen S, Schratt G (2010) Recombinant adeno-associated virus-mediated microRNA delivery into the postnatal mouse brain reveals a role for miR134 in dendritogenesis in vivo. Front Neural Circuits 3:16

91. Krichevsky AM, Sonntag KC, Isacson O, Kosik KS (2006) Specific microRNAs modulate embryonic stem cell-derived neurogenesis. Stem Cells 24(4):857-864
92. Zhao C, Sun G, Li S, Shi Y (2009) A feedback regulatory loop involving microRNA-9 and nuclear receptor TLX in neural stem cell fate determination. Nat Struct Mol Biol 16(4):365-371

93. Shibata M, Kurokawa D, Nakao H, Ohmura T, Aizawa S (2008) MicroRNA-9 modulates Cajal-Retzius cell differentiation by suppressing Foxg1 expression in mouse medial pallium. J Neurosci 28(41):10415-10421

94. Shibata M, Nakao H, Kiyonari H, Abe T, Aizawa S (2011) MicroRNA-9 regulates neurogenesis in mouse telencephalon by targeting multiple transcription factors. J Neurosci 31(9): 3407-3422

95. Bruno Ig, Karam R, Huang L, Bhardwaj A, Lou CH, Shum EY, Song HW, Corbett MA, Gifford WD, Gecz J, Pfaff SL, Wilkinson MF (2011) Identification of a microRNA that activates gene expression by repressing nonsense-mediated RNA decay. Mol Cell 42(4):500-510

96. Parsons MJ, Grimm CH, Paya-Cano JL, Sugden K, Nietfeld W, Lehrach H, Schalkwyk LC (2008) Using hippocampal microRNA expression differences between mouse inbred strains to characterise miRNA function. Mammalian Genome 19:552-560

97. Smalheiser NR, Lugli G, Lenon AL, Davis JM, Torvik VI, Larson J (2010) Olfactory discrimination training up-regulates and reorganizes expression of microRNAs in adult mouse hippocampus. ASN Neuro 2(1):39-48

98. Konopka W, Kiryk A, Novak M, Herwerth M, Parkitna JR, Wawrzyniak M, Kowarsch A, Michaluk P, Dzwonek J, Arnsperger T, Wilczynski G, Merkenschlager M, Theis FJ, Kohr G, Kaczmarek L, Schutz G (2010) MicroRNA loss enhances learning and memory in mice. J Neurosci 30(44):14835-14842

99. Hunsberger JG, Austin DR, Chen G, Manji HK (2009) MicroRNAs in mental health: from biological underpinnings to potential therapies. Neuromol Med 11(3):173-182

100. Kuhn DE, Nuovo GJ, Terry AV Jr, Martin MM, Malana GE, Sansom SE, Pleister AP, Beck WD, Head E, Feldman DS, Elton TS (2010) Chromosome 21-derived microRNAs provide an etiological basis for aberrant protein expression in human Down syndrome brains. J Biol Chem 285(2):1529-1543

101. Szulwach KE, Li X, Smrt RD, Li Y, Luo Y, Lin L, Santistevan NJ, Li W, Zhao X, Jin P (2010) Cross talk between microRNA and epigenetic regulation in adult neurogenesis. J Cell Biol 189(1):127-141

102. Abu-Elneel K, Liu T, Gazzaniga FS, Nishimura Y, Wall DP, Geschwind DH, Lao K, Kosik SK (2008) Heterogeneous dysregulation of microRNAs across the autism spectrum. Neurogenetics 9:153-161

103. Zhou R, Yuan P, Wang Y, Hunsberger JG, Elkahloun A, Wei Y, Damschroder-Williams P, Du J, Chen G, Manji HK (2009) Evidence for selective microRNAs and their effectors as common long-term targets for the actions of mood stabilizers. Neuropsychopharmacology 34(6):1395-1405

104. Tan H, Li H, Jin P (2009) RNA-mediated pathogenesis in fragile $\mathrm{X}$-associated disorders. Neurosci Lett 466(2):103-108

105. Xu XL, Li Y, Wang F, Gao FB (2008) The steady-state level of the nervous-system-specific microRNA-124a is regulated by dFMR1 in Drosophila. J Neurosci 28(46):11883-11889

106. Perkins DO, Jeffries CD, Jarskog LF, Thomson JM, Woods K, Newman MA, Parker JS, Jin J, Hammond SM (2007) microRNA expression in the prefrontal cortex of individuals with schizophrenia and schizoaffective disorder. Genome Biol 8:2

107. Beveridge NJ, Tooney PA, Carroll AP, Gardiner E, Bowden N, Scott RJ, Tran N, Dedova I, Cairns MJ (2008) Dysregulation of miRNA $181 \mathrm{~b}$ in the temporal cortex in schizophrenia. Hum Mol Genet 17(8):1156-1168

108. Kocerha J, Faghihi MA, Lopez-Toledano MA, Huang J, Ramsey AJ, Caron MG, Sales N, Willoughby D, Elmen J, Hansen HF, Orum H, Kauppinen S, Kenny PJ, Wahlestedt C (2009) 
MicroRNA-219 modulates NMDA receptor-mediated neurobehavioral dysfunction. PNAS 106(9):3507-3512

109. Krützfeldt J, Rajewsky N, Braich R, Rajeev KG, Tuschl T, Manoharan M, Stoffel M (2005) Silencing of microRNAs in vivo with 'antagomirs'. Nature 438(7068):685-689

110. Faghihi MA, Zhang M, Huang J, Modarresi F, Van Der Brug MA, Nalls MA, Cookson MR, St-Laurent G, Wahlestedt C (2010) Evidence for natural antisense transcript-mediated inhibition of microRNA function. Genome Biol 11:5

111. Hebert SS, De Strooper B (2009) Alterations of the microRNA network cause neurodegenerative disease. Trends Neurosci 32(4):199-206

112. Kim J, Inoue K, Ishii J, Vanti WB, Voronov SV, Murchinson E, Hannon G, Albeliovish A (2007) A microRNA feedback circuit in midbrain dopamine neurons. Science 317(5842):1220-1224

113. Lewis MA, Quint E, Glazier AM, Fuchs H, De Angelis MH, Langford C, Van Dongen S, Abreu-Goodger C, Piipari M, Redshaw N, Dalmay T, Moreno-Pelayo MA, Enright AJ, Steel KP (2009) An ENU-induced mutation of miR-96 associated with progressive hearing loss in mice. Nat Genet 41(5):614-618

114. Abelson JF, Kwan KY, O'roak BJ, Baek DY, Stillman AA, Morgan TM, Mathews CA, Pauls DL, Rašin MR, Gunel M, Davis NR, Ercan-Sencicek AG, Guez DH, Spertus JA, Leckman JF, Dure LS, Kurlan R, Singer HS, Gilbert DL, Farhi A, Louvi A, Lifton RP, Sestan N, State MW (2005) Sequence variants in SLITRK1 are associated with Tourette's syndrome. Science 310(5746):317-320

115. Rajasethupathy P, Fiumara F, Sheridan R, Betel D, Puthanveettil SV, Russo JJ, Sander C, Tuschl T, Kandel E (2009) Characterization of small RNAs in Aplysia reveals a role for miR-124 in constraining synaptic plasticity through CREB. Neuron 63(6):803-817

116. Kawashima H, Numakawa T, Kumamaru E, Adachi N, Mizuno H, Ninomiya M, Kunugi H, Hashido K (2010) Glucocorticoid attenuates brain-derived neurotrophic factor-dependent upregulation of glutamate receptors via the suppression of microRNA132 expression. Neuroscience 165(4):1301-1311

117. Gaughwin P, Ciesla M, Yang H, Lim B, Brundin P (2011) Stage-specific modulation of cortical neuronal development by mmu-miR-134. Cerebral Cortex 21(8):1857-1869

118. Abdelmohsen K, Hutchison ER, Lee EK, Kuwano Y, Kim MM, Masuda K, Srikantan S, Subaran SS, Marasa BS, Mattson MP,
Gorospe M (2010) miR-375 inhibits differentiation of neurites by lowering HuD levels. Mol Cell Biol 30(17):4197-4210

119. Packer AN, Xing Y, Harper SQ, Jones L, Davidson BL (2008) The bifunctional microRNA miR-9/miR-9* regulates REST and CoREST and is downregulated in Huntington's disease. J Neurosci 28(53):14341-14346

120. Shioya M, Obayashi S, Tabunoki H, Arima K, Saito Y, Ishida T, Satoh J (2010) Aberrant microRNA expression in the brains of neurodegenerative diseases: miR-29a decreased in Alzheimer disease brains targets neurone navigator 3. Neuropathol Appl Neurobiol 36(4):320-330

121. Hébert SS, Horré K, Nicolaï L, Papadopoulou AS, Mandemakers W, Silahtaroglu AN, Kauppinen S, Delacourte A, De Strooper B (2008) Loss of microRNA cluster miR-29a/b-1 in sporadic Alzheimer's disease correlates with increased BACE1/ beta-secretase expression. PNAS 105(17):6415-6420

122. Wang WX, Rajeev BW, Stromberg AJ, Ren N, Tang G, Huang Q, Rigoutsos I, Nelson PT (2008) The expression of microRNA miR-107 decreases early in Alzheimer's disease and may accelerate disease progression through regulation of beta-site amyloid precursor protein-cleaving enzyme 1. J Neurosci 28(5):1213-1223

123. Urdinguio RG, Fernandez AF, Lopez-Nieva P, Rossi S, Huertas D, Kulis M, Liu CG, Croce C, Calin GA, Esteller M (2010) Disrupted microRNA expression caused by Mecp2 loss in a mouse model of Rett syndrome. Epigenetics 5:7

124. Boissonneault V, Plante I, Rivest S, Provost P (2009) MicroRNA-298 and microRNA-328 regulate expression of mouse betaamyloid precursor protein-converting enzyme 1. J Biol Chem 284(4):1971-1981

125. Montag J, Hitt R, Opitz L, Schulz-Schaeffer W.J, Hunsmann G, Motzkus D (2009) Upregulation of miRNA hsa-miR-342-3p in experimental and idiopathic prion disease. Mol Neurodegen 4:36-42

126. Huntzinger E, Izaurralde E (2011) Gene silencing by microRNAs: contributions of translational repression and mRNA decay. Nat Rev Genet 12(2):99-110

127. Vasudevan S, Tong Y, Steitz JA (2007) Switching from repression to activation: microRNAs can up-regulate translation. Science 318:1931-1934 